\title{
TU/e EmonONEN

\section{Reactivity of oxygen adsorbed on silver powder in the epoxidation of ethylene}

\section{Citation for published version (APA):}

Backx, C., Moolhuysen, J., Geenen, P., \& Santen, van, R. A. (1981). Reactivity of oxygen adsorbed on silver powder in the epoxidation of ethylene. Journal of Catalysis, 72(2), 364-368. https://doi.org/10.1016/00219517\%2881\%2990019-1, https://doi.org/10.1016/0021-9517(81)90019-1

\section{DOI:}

10.1016/0021-9517\%2881\%2990019-1

10.1016/0021-9517(81)90019-1

Document status and date:

Published: 01/01/1981

\section{Document Version:}

Publisher's PDF, also known as Version of Record (includes final page, issue and volume numbers)

\section{Please check the document version of this publication:}

- A submitted manuscript is the version of the article upon submission and before peer-review. There can be important differences between the submitted version and the official published version of record. People interested in the research are advised to contact the author for the final version of the publication, or visit the $\mathrm{DOI}$ to the publisher's website.

- The final author version and the galley proof are versions of the publication after peer review.

- The final published version features the final layout of the paper including the volume, issue and page numbers.

Link to publication

\section{General rights}

Copyright and moral rights for the publications made accessible in the public portal are retained by the authors and/or other copyright owners and it is a condition of accessing publications that users recognise and abide by the legal requirements associated with these rights.

- Users may download and print one copy of any publication from the public portal for the purpose of private study or research.

- You may not further distribute the material or use it for any profit-making activity or commercial gain

- You may freely distribute the URL identifying the publication in the public portal.

If the publication is distributed under the terms of Article 25fa of the Dutch Copyright Act, indicated by the "Taverne" license above, please follow below link for the End User Agreement:

www.tue.nl/taverne

Take down policy

If you believe that this document breaches copyright please contact us at:

openaccess@tue.nl

providing details and we will investigate your claim. 


\section{NOTES}

\section{Reactivity of Oxygen Adsorbed on Silver Powder in the Epoxidation of Ethylene}

It has been recognized that in the oxidation of ethylene over a silver catalyst the selectivity to ethylene oxide is highly determined by the mode of adsorption of oxygen on silver $(I-3)$. However, there is no general consensus as to which oxygen species is active in the epoxidation of ethylene. Recently, it has been shown by application of high-resolution electron energy loss spectroscopy (EELS) in conjunction with temperature-programmed desorption (TPD) that three different types of adsorbed oxygen can be distinguished on the (110) plane of silver after exposure to oxygen at pressures $<10^{-3} \mathrm{~Pa}(4)$. A single type of adsorbed diatomic oxygen was detected, which dissociated at $-100^{\circ} \mathrm{C}$ and was shown to be the precursor of adsorbed monoatomic oxygen. At temperatures between -100 and $+310^{\circ} \mathrm{C}$, two atomic states may coexist. In one of these states the atom is adsorbed in a fourfold coordinated site on the surface and desorbs at $310^{\circ} \mathrm{C}$, while in the second state atomic oxygen is present below the surface and does not desorb at temperatures below $450^{\circ} \mathrm{C}$. Occupation of subsurface sites takes place by diffusion of adsorbed atomic oxygen, which occurs above $100^{\circ} \mathrm{C}$.

These observations are of interest in view of a model proposed by Temkin (5).

'He postulates that the presence of surface oxide is essential for the epoxidation of ethylene, the oxygen of this surface oxide being necessary but not active in the epoxidation reaction itself.

In order to clarify the role of subsurface oxygen we have done a number of temperature-programined reaction experiments using $\mathrm{C}_{2} \mathrm{D}_{4}$ with oxygen adsorbed on silver powder. Powders were used in order to ensure a high silver surface area. Oxygen was adsorbed at 20 and $200^{\circ} \mathrm{C}$ since TPD and EELS experiments (4) had indicated that at $20^{\circ} \mathrm{C}$ no subsurface oxygen is created at a (110) surface. It should be noted, however, that so far this has only been found for Ag surfaces which had been exposed to oxygen pressure not higher than $10^{-2} \mathrm{~Pa}$.

The silver sample consisted of $10 \mathrm{~g}$ of silver powder, which before each measurement was cleaned by repeated oxidations and reductions, with a final hydrogen treatment at $300^{\circ} \mathrm{C}$ and 1 bar for $16 \mathrm{~h}$, followed by evacuation for a few hours at $300^{\circ} \mathrm{C}$. The amount of oxygen adsorbed at $200^{\circ} \mathrm{C}$ is plotted in Fig. 1 as a function of time. A very fast and a slow activated adsorption can be distinguished, in agreement with the findings of Kilty et al. (I). After $30 \mathrm{~min}$ an amount of $10 \mu \mathrm{mol} \mathrm{O}{ }_{2}$ is adsorbed, increasing to $10.2 \mu \mathrm{mol}$ after $45 \mathrm{~min}$. Only a small amount $(7 \%)$ of this oxygen is desorbed upon evacuation for $30 \mathrm{~min}$ at $200^{\circ} \mathrm{C}$. Temperature-programmed desorption up to $300^{\circ} \mathrm{C}$ results in a single peak at $290^{\circ} \mathrm{C}$ analogous to the findings in TPD measurements on $\mathrm{Ag}$ (110) (4) and $\mathrm{Ag}$ (111) (6). The amount desorbed from the powder during evacuation at $200^{\circ} \mathrm{C}$ and the TPD experiment is $4.2 \mu \mathrm{mol}$, so in other words, 6.0 $\mu$ mol remains undesorbed. The EELS measurements have shown for the (110) surface that after desorption at $300^{\circ} \mathrm{C}$ no surface oxygen is present, so that we postulate that in the Ag powder the $6.0 \mu \mathrm{mol}$ are accommodated in the subsurface layers. That this subsurface oxygen is also present after adsorption for $30 \mathrm{~min}$ at $200^{\circ} \mathrm{C}$ is evidenced by 


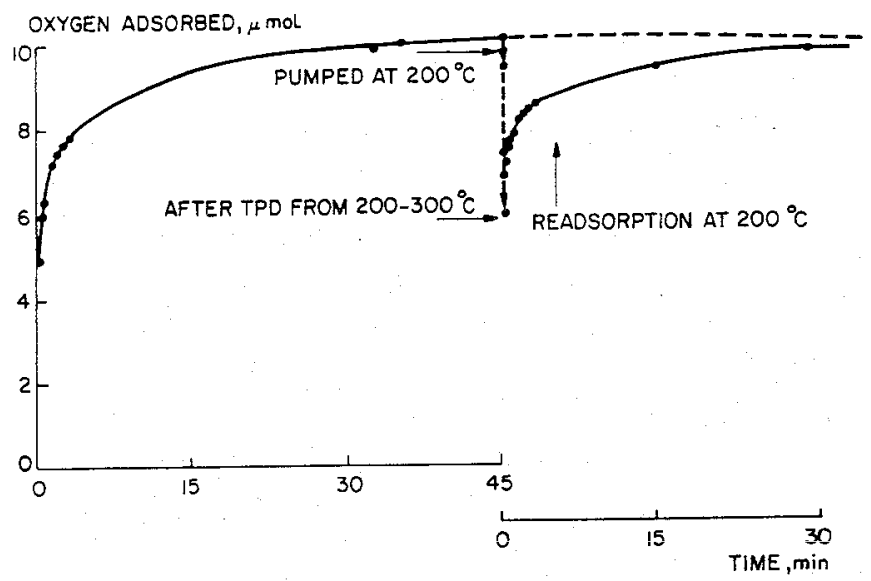

Fig. 1. Amount of oxygen adsorbed as a function of time and temperature.

the fact that after the treatment at $300^{\circ} \mathrm{C}$ readsorption at $200^{\circ} \mathrm{C}$ results in the same amount and the same kinetics of oxygen adsorption (Fig. 1). In another experiment oxygen was adsorbed at 200 and $20^{\circ} \mathrm{C}$ for 30 min at $100 \mathrm{~Pa}$ and the vessel containing the sample was evacuated at various temperatures. Subsequently $100 \mathrm{~Pa} \mathrm{C}_{2} \mathrm{D}_{4}$ and $100 \mathrm{~Pa}$ Ar were admitted at $-80^{\circ} \mathrm{C}$ and the reaction vessel closed. Then the silver was heated at a rate of $5^{\circ} \mathrm{C} / \mathrm{min}$, while every $3 \mathrm{~min}$ a small amount of the gas was analysed with a mass spectrometer, where the Ar signal served as a calibration for the pressure of $\mathrm{EO}$ and $\mathrm{CO}_{2}$ in the vessel. Since the sampling of gas resulted in a small drop of the overall pressure in the vessel and therefore also of the pressure of $\mathrm{Ar}$ the amounts of $\mathrm{CO}_{2}$ and EO are systematically too high by $\sim 15 \%$ at temperatures above $200^{\circ} \mathrm{C}$, the error becoming smaller towards lower temperatures, where less gas was removed for sampling. The amounts of $\mathrm{CO}_{2}$ and ethylene oxide (EO) formed after adsorption of $10 \mu \mathrm{mol} \mathrm{O}_{2}$ at $200^{\circ} \mathrm{C}$ and subsequent evacuation at $-80^{\circ} \mathrm{C}$ are plotted in Fig. 2. A maximum amount of $\mathrm{EO}$ is obtained at $135^{\circ} \mathrm{C}$; the subsequent decrease in $\mathrm{EO}$ shows that $\mathrm{EO}$ is further oxidized to $\mathrm{CO}_{2}$, as is also evidenced by an increase in $\mathrm{CO}_{2}$. As this consecutive reaction may also take place below $135^{\circ} \mathrm{C}$ the quantity of $\mathrm{EO}$ ob- served at this temperature is a lower limit for the quantity initially formed.

The amounts of $\mathrm{CO}_{2}$ and $\mathrm{EO}$ detected at 300 and $135^{\circ} \mathrm{C}$, respectively, after various oxygen pretreatments of the silver are given in the last two columns of Table 1. The first five columns show the temperature at which oxygen is adsorbed, the amount adsorbed in $30 \mathrm{~min}$, the temperature at which the vessel was evacuated after the adsorption, the amount desorbed by evacuation and finally the amount of oxygen still present on the silver before $\mathrm{C}_{2} \mathrm{D}_{4}$ was admitted. Only in experiments 1 and 2 was EO detected, while the other oxygen pretreatments only resulted in the production of $\mathrm{CO}_{2}$. Since it has been indicated that several types of oxygen are found by adsorption at different temperatures, it can be concluded that the various types of oxygen lead to different selectivities. In column 6 the modes of the adsorbed oxygen are roughly classified in terms of surface (S) and subsurface (SS) oxygen. This classification is based on temperatureprogrammed desorption measurements of oxygen adsorbed on the (110) and the (111) plane of silver single crystals $(4,6)$. In Refs. (4) and (6) it was shown that desorption of surface oxygen takes place at $\sim 300^{\circ} \mathrm{C}$, while the oxygen remaining on the surface was shown to be subsurface oxy- 


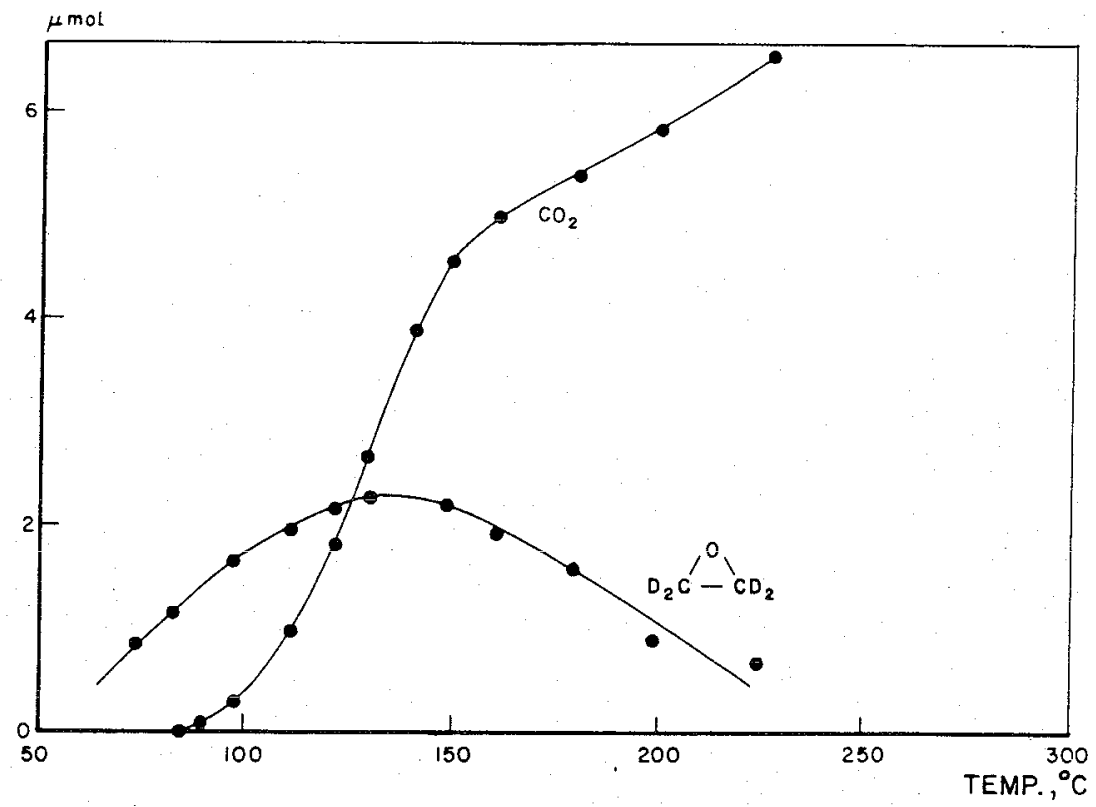

FIG. 2. Temperature-programmed reaction of $10 \mu \mathrm{mol} \mathrm{O}_{2}$ chemisorbed on $\mathrm{Ag}$ with $\mathrm{C}_{2} \mathrm{D}_{4}$.

gen, the diffusion of surface oxygen to subsurface sites occurring at temperatures above $100^{\circ} \mathrm{C}$.

The data allow the following conclusions to be drawn:

-Of the oxygen adsorbed at $200^{\circ} \mathrm{C}$ (total $1.2 \times 10^{15}$ atoms $/ \mathrm{cm}^{2}$ ) about $50 \%$ is present as subsurface oxygen.

-EO is formed only if both surface and subsurface oxygen are present.

-Subsurface oxygen in the absence of surface oxygen gives total combustion upon reaction with ethylene (Exps. 3, 4).

-Of the total number of oxygen atoms present on or below the surface $\left(1.2 \times 10^{15}\right.$ atoms $/ \mathrm{cm}^{2}$ ) in Exp. 1 at least $11 \%$ is active in the formation of EO.

-The active oxygen species resists evacuation at $200^{\circ} \mathrm{C}$ (Exps. 1, 2), which makes it accessible to modern surface analytical techniques.

The dependence of the selectivity on

TABLE 1

The Adsorption', Desorption, and Reactivity of Oxygen on Silver Powder ${ }^{a}$

\begin{tabular}{|c|c|c|c|c|c|c|c|c|}
\hline \multirow[t]{2}{*}{ Exp. } & \multicolumn{5}{|c|}{ Adsorption-desorption of $\mathrm{O}_{2}$} & \multirow[t]{2}{*}{ Mode $^{b}$} & \multicolumn{2}{|c|}{ Quantity produced } \\
\hline & $\begin{array}{l}T_{\text {ads }} \\
\left({ }^{\circ} \mathrm{C}\right)\end{array}$ & $\begin{array}{l}\mathrm{O}_{2} \text { ads } \\
(\mu \mathrm{mol})\end{array}$ & $\begin{array}{l}T_{\text {evac. }} \\
\left({ }^{\circ} \mathrm{C}\right)\end{array}$ & $\begin{array}{l}\mathrm{O}_{2} \text { des. } \\
(\mu \mathrm{mol})\end{array}$ & $\begin{array}{c}\mathrm{O}_{2} \text { present } \\
(\mu \mathrm{mol})\end{array}$ & & $\begin{array}{c}\mathrm{CO}_{2} \text { at } 300^{\circ} \mathrm{C} \\
(\mu \mathrm{mol})\end{array}$ & $\begin{array}{c}\mathrm{EO} \text { at } 135^{\circ} \mathrm{C} \\
(\mu \mathrm{mol})\end{array}$ \\
\hline 1 & 200 & 10 & -80 & 0 & 10 & $S+S S$ & 8.3 & 2.23 \\
\hline 2 & 200 & 10 & 200 & 0.5 & 9.5 & $S+S S$ & 7.7 & 1.90 \\
\hline 3 & 200 & 10 & 300 & 4.8 & 5.2 & SS & 2.5 & 0 \\
\hline $4^{c}$ & 200 & 4.9 & 200 & 0 & 4.9 & SS & 2.6 & 0 \\
\hline 5 & 20 & 3.6 & 20 & 0 & 3.6 & $S$ & 2.4 & 0 \\
\hline
\end{tabular}

${ }^{a} \mathrm{O} / \mathrm{Ag}=1$ corresponds to $\approx 1.2 \times 10^{15}$ atoms $/ \mathrm{cm}^{2}$ or $10 \mu \mathrm{mol} / 10 \mathrm{~g} \mathrm{Ag}$.

${ }^{b} \mathrm{~S}=$ surface; $\mathrm{SS}=$ subsurface; information derived from EELS (4).

${ }^{c}$ In experiment 4 a pressure lower than $10^{2} \mathrm{~Pa}$ has been used. 
coverage, as shown in Table 1 , is similar to that previously found by Gruver et al. (3). Below a coverage of $\mathrm{O} / \mathrm{Ag}=0.35$ no ethylene oxide was formed, while at higher coverages the amount of $\mathrm{EO}$ increased with oxygen coverage. The degree of conversion of the adsorbed oxygen into ethylene oxide did not exceed 5\% under their oxygen adsorption conditions. The higher maximum concentration of active oxygen found in our experiments $(11 \%)$ is due to the higher oxygen coverage obtained at $200^{\circ} \mathrm{C}$ and possibly also to the fact that we used $\mathrm{C}_{2} \mathrm{D}_{4}$ instead of $\mathrm{C}_{2} \mathrm{H}_{4}(7)$.

The concentration of oxygen species observed to be active in ethylene oxide formation $(>11 \%)$ is much higher than the $\mathrm{O}_{2}^{-}$ concentration $(0.02 \%)$ detected by electron paramagnetic resonance spectroscopy (8), which so far is the only technique that has actually revealed the adsorption of a diatomic oxygen radical species at temperatures above $0^{\circ} \mathrm{C}$. From this we may conclude either that the diatomic oxygen radical is not the active species in the epoxidation, or that the formal charge of the diatomic species is very small.

The present work is complementary to the recent work of Kagawa et al. (9), who measured the amount of $\mathrm{EO}$ and $\mathrm{CO}_{2}$ formed after contacting 0.4 bar ethylene at $180^{\circ} \mathrm{C}$ with various amounts of oxygen preadsorbed on silver at a temperature of $180^{\circ} \mathrm{C}$. The amount of oxygen adsorbed was derived from the amount of oxygen desorbing around $300^{\circ} \mathrm{C}$, while in the present article both the amount adsorbed and the amount desorbed were measured. If this difference is taken into account, Kagawa et al. find that at maximum $20 \%$ of the oxygen adsorbed on the surface is active in the formation of $\mathrm{EO}$.

We checked that the rate of epoxidation under catalytic conditions is of the same order of magnitude as that found in our surface reaction experiment by comparing data from Imre (10) with data derived from Fig. 2. The chance $\gamma$ that an ethylene molecule impinging on the oxygen-covered silver surface reacts to give ethylene oxide may be estimated from the slope, at $75^{\circ} \mathrm{C}$, of the curve representing the amount of ethylene oxide formed in Fig. 2. A value of $10^{-10}$ is found for $\gamma$ at $75^{\circ} \mathrm{C}$. Imre $(10)$ found that at $300^{\circ} \mathrm{C}$ and an oxygen pressure of 0.25 bar the rate of $\mathrm{EO}$ formation was $6 \times$ $10^{-10} \mathrm{~mol} / \mathrm{cm}^{2} \cdot \mathrm{s}$, which gives a $\gamma$ of $1.3 \times$ $10^{-8}$. In order to compare this $\gamma$ with the one found from the TPR experiments, we normalized both to a temperature of $200^{\circ} \mathrm{C}$ by making use of an activation energy of 34 $\mathrm{kJ} / \mathrm{mol}(10)$. This is the lowest activation energy reported so far $(l /)$. In this way we obtained values of $2.2 \times 10^{-9}$ and $3.0 \times 10^{-9}$ for the $\gamma$ 's found from this work and that of Imre, respectively.

Our results lead to the tentative conclusion that EO is formed if both surface and subsurface oxygen are formed. The overlayer formed by silver and oxygen ions, containing subsurface oxygen, may be similar to the surface oxide proposed by Temkin (5), to which the oxygen species active in the epoxidation reaction becomes adsorbed.

Experiments are in progress to verify this model via a spectroscopic investigation of the oxygen species adsorbed on silver at a pressure of $100 \mathrm{~Pa}$ and $200^{\circ} \mathrm{C}$.

Our results imply that in further experiments directed towards elucidating the mechanism of ethylene epoxidation, it will be essential to establish a surface overlayer simulating the steady-state surface composition. The finding that the oxygen species responsible for epoxidation is stable with respect to evacuation makes study of this surface layer accessible to modern surface techniques.

\section{REFERENCES}

I. Kilty, P. A., Rol, N. C., and Sachtler, W. M. H., in "Proceedings, 5th International Congress on Catalysis, Florida 1972," p. 929, NorthHolland/American Elsevier, Amsterdam, 1973.

2. Force, E. L., and Bell, A. T., J. Catal. 40, 356 (1975). 
3. Gruver, V. Sh., Khasin A. V., Boreskov, G. K., and Kotovets, O. E., Dokl. Akad. Nauk SSSR (Dankes), 208, 1379 (1973).

4. Backx, C., de Groot, C. P. M., and Biloen, P. Surface Sci. 104, 300 (1981).

5. Temkin, M. I., in "Advances in Catalysis" (D. D. Eley, H. Pines, and P. B. Weisz, Eds.), Vol. 28, p. 173. Academic Press, New York, 1978.

6. Rovida, G., Pratesi, F., Maglietta, M., and Ferroni, E., Surface Sci. 43, 230 (1974).

7. Cant, N. W., and Hall, W. K., J. Catal. 52, 81 (1978); van Santen, R. A., Moolhuysen, J., and Sachtler, W. M. H., J. Catal. 65, 478 (1980).

8. Clarkson, R. B., and Cirillo, A. C., Jr., J. Catal. 33, 392 (1974).

9. Kagawa, S., Iwamoto, M., and Mori, H., submitted for publication.

10. Imre, L., Ber. Bunsenges. Phys. Chem. 74, 220 (1970).
11. Sachtler, W. M. H., Backx; C., and van Santen, R. A., Catal. Rev.-Sci. Eng. 23, 127 (1981).

C. BACKX

J. MOOLHUYSEN

P. GEENEN

R. A. VAN SANTEN

Koninklijke/Shell-Laboratorium

Badhuisweg 3

103l CM Amsterdam-N

The Netherlands

Received November 11,1980 revised March. 1 , 1981 